\section{Interactions between insect pollinators and the ornamental tree, Tecoma stans (L.)}

\section{K. Henry Jonathan ${ }^{1}$, A.J. Solomon Raju ${ }^{2}$, K. Suseela Branham ${ }^{1} \&$ D. Sunanda Devi ${ }^{1}$}

1,2 Department of Environmental Sciences, Andhra University, Visakhapatnam, Andhra Pradesh 530003, India

Email: ${ }^{2}$ ajsraju@yahoo.com (corresponding author)

Hawk moths (Lepidoptera: Sphingidae) are distributed worldwide, concentrated in the tropical regions (Arnett 1985) The adults are nectarivorous and feed on different plant species; while feeding they bring about pollination (Borkent \& Greenway 1997; Kumar 2000). A specific characteristic of hawk moths is that they do not land on the flower for nectar collection; they remove nectar very quick and fly very fast from flower to flower and plant to plant, a behaviour which is important for cross-pollination.

In India, little information is available on hawk moths with reference to their relationship with plant species. Raju et al. (2004) reported on the interaction of the hawkmoth, Macroglossum gyrans with certain plant species at Visakhapatnam. The present study examines the relationship between different species of hawk moths and Tecoma stans, a widely-cultivated ornamental exotic tree species in tropical latitudes.

Cultivated trees of T. stans in the Andhra University campus were used for the study. Flower nectar volume was measured by using graduated micro capillary tubes; for this purpose twenty bagged flowers were used. Nectar sugar concentration was recorded by using a Sugar Hand Refractometer. Nectar sugar types and amino acids present in nectar were ascertained following the paper chromatography methods described by Baker \& Baker (1973). The correlation between flower corolla length and nectar volume/sugar concentration was also examined by statistical analysis. Forager species were observed from dawn to dusk and in the night for foraging activity. They were captured using an insect net, killed using ethyl alcohol, preserved in air tight glass boxes and identified by comparing

Date of online publication 26 February 2009

ISSN $0974-7907$ (online) | 0974-7893 (print)

Editor: K.R. Sasidharan

\section{Manuscript details:}

Ms \# 01871

Received 11 October 2007

Final revised received 24 May 2008

Finally accepted 16 June 2008

Citation: Jonathan, K.H., A.J.S. Raju, K.S. Branham \& D.S. Devi (2009). Interactions between insect pollinators and the ornamental tree, Tecoma stans (L.). Journal of Threatened Taxa 1(2): 126-127.

Copyright: () K.H. Jonathan, A.J.S. Raju, K.S. Branham \& D.S. Devi 2009 Creative Commons Attribution 3.0 Unported License. JoTT allows unrestricted use of this article in any medium for non-profit purposes, reproduction and distribution by providing adequate credit to the authors and the source of publication.

OPEN AGCESS | FREE DOWNLOAD them with specimens already identified and available in the Department of Environmental Sciences, Andhra University. The foraging schedules of hawk moths were defined by making field observations. The hawk moths were observed for their flowerhandling behaviour, forage sought, speed at which the forage was collected and the consistency of foraging activity.

Tecoma stans flowers throughout the year, with intense flowering during October-May. The flowers open daily during 0500-0800 hr and again during 1500-1700 hr (Rao et al. 2005). Flowers occur in small clusters at the ends of the branches and are trumpet-shaped with five rounded lobes. The flowers are about $6 \mathrm{~cm}$ long, pale to bright yellow, with faint orange stripes at the throat, mildly scented, bisexual and zygomorphic. The nectar volume is $3.01 \pm 0.98 \mu \mathrm{l}$ per flower with a sugar concentration of $29.8 \pm 1.77 \%$; the common sugars include hexoses, glucose and fructose amounting to $0.99 \pm 0.3 \mathrm{mg}$. There is a significant correlation between corolla tube length and the nectar volume at 0.01 level $(r=0.655, \mathrm{~N}=20)$, while there is no correlation between corolla tube length and nectar sugar concentration $(\mathrm{r}=-0.253, \mathrm{~N}=20$ ) (Table 1). Nineteen of the twenty conventional amino acids were tested for their presence in the nectar. The study revealed the presence of eleven amino acids which included glycine, serine, proline, arginine, glutamic acid, cystine, cysteine, lysine, histidine, threonine and alanine.

The hawk moths foraged for nectar during two time periods: 0530-0700 hr and 1630-1830 hr (Fig. 1). Other foragers included bees (Apis dorsata, A. cerana indica, Trigona iridipennis, Amegilla sp., Xylocopa latipes, X. pubescens, Ceratina simillima and Pithitis binghami) and wasps, Vespa sp. All of these species foraged throughout the daytime until 1700hrs; the bees collected both pollen and nectar while the wasps collected only nectar. Hawk moths included Agrius convolvuli L., Macroglossum sitiene Walker, M. gyrans Walker, Nephele hespera Fabr. and Hippotion rosetta Swinhoe. They hovered at the flowers, inserted proboscis and obtained nectar in 1 or 2 seconds.

The study shows that $T$. stans flowers with two anthesis schedules attract bees, wasps and hawk moths at different times of the day. The morning anthesis provides the required forage for bees and wasps while the afternoon anthesis is primarily intended for attracting the hawk moths, as bees and wasps do not forage beyond $1700 \mathrm{hr}$. This situation is reflected in the temporal separation of foraging schedules of these different groups of foragers. The horizontal position of the flower, tubular corolla, yellow colour, emission of scent and small volume of nectar are characteristics of hawk moth flowers (Meeuse \& Morris 1984). The sugar concentration in nectar is at moderate level and it is important to note that low viscosity is necessary for hawk moths to take nectar very quickly as they spend a very brief period at the flowers (Baker 1975, 1978). Hawk moth flowers have been reported to be sucrose-rich (Baker \& Baker 1983a,b). But, in T. stans, the nectar contains only hexose sugars, glucose and fructose. However, hawk moth species consistently use this nectar as energy source during the entire period of flowering.

Dadd (1973) reported that insects require ten essential amino acids namely, threonine, valine, methionine, leucine, iso-leucine, phenylalanine, lysine, histidine, arginine and 
Table 1. Nectar volume and sugar concentration of Tecoma stans

\begin{tabular}{llll}
\hline $\begin{array}{l}\text { Nectar volume/flower }(\mu \mathrm{l}) \\
\text { Mean } \pm \text { S.D. }\end{array}$ & $\begin{array}{l}\text { Sugar concentration/ } \\
\text { flower Mean } \pm \text { S.D. }\end{array}$ & $\begin{array}{l}\text { Amount of sugar/ } \\
\text { flower Mean } \pm \text { S.D. }\end{array}$ & $\begin{array}{l}\text { Correlation between nectar volume } \\
\text { and corolla tube length }(r)^{*}\end{array}$ \\
\hline $3.01 \pm 0.98$ & $29.8 \pm 1.77$ & $0.99 \pm 0.3$ & 0.655 \\
\hline
\end{tabular}

Sample size $=20$ flowers. ${ }^{*}$ Significance at 0.01 level.

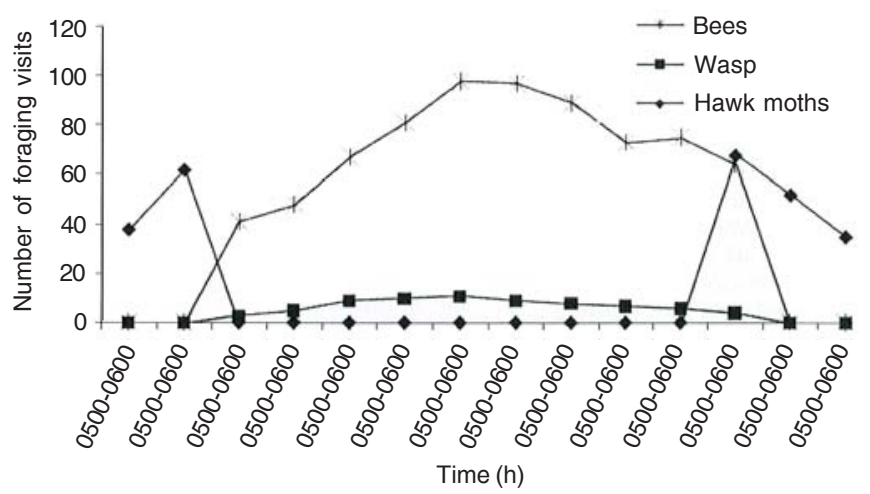

Figure 1. Foraging activity of foragers on Tecoma stans

tryptophan. The present study indicated that the nectar of $T$. stans is a source of three of these amino acids, lysine, histidine and threonine and also of other non-essential amino acids, glycine, serine, proline, arginine, glutamic acid, cystine, cysteine and alanine. It is reported that the nectars of haw kmoth flowers are low in amino acid concentration (Baker \& Baker 1982). However, the nectar of T. stans is an assured source of hexose sugars, some essential and non-essential amino acids for the adult hawk moths.

The study shows that Tecoma stans with a long period of flowering is an important nectar source for the hawk moths. Different species of hawk moths use T. stans as a good feeding station, though it is not a native nectar source for them. Further, T. stans with its afternoon anthesis schedule attracts hawk moths and achieves pollination by providing the nutritionally rich nectar as a reward, thus exhibiting a mutualistic relationship between hawk moths and T. stans. Further, T. stans is also important as a pollen and nectar source for bees, and a nectar source for wasps.

\section{References}

Arnett, R.H. Jr. (1985). American Insects: A Handbook of the Insects of America North of Mexico. Van Nostrand Reinhold Company, New York, $850 \mathrm{pp}$.

Baker, H.G. (1975). Sugar concentration in nectars from hummingbird flowers. Biotropica 7: 37-41.

Baker, H.G. (1978). Chemical aspects of pollination of woody plants in tropics, pp.57-82. In: Tomlinson, P.B. \& M.H. Zimmermann (Eds.). Tropical Trees as Living Systems. Cambridge University Press, Cambridge.

Baker, H.G. \& I. Baker (1973). Some anthecological aspects of the evolution of nectar-producing flowers, particularly amino acid production, pp.243-264. In: Heywood, V.H. (Ed.). Taxonomy and Ecology. Academic Press, London.

Baker, H.G. \& I. Baker (1982). Chemical constituents of nectar in relation to pollination mechanisms and phylogeny, pp.131-171. In: Nitecki, H.M. (Ed.). Biochemical Aspects of Evolutionary Biology. University of Chicago Press, Chicago.

Baker, H.G. \& I. Baker (1983a). A brief historical review of the chemistry of floral nectar, pp.81-152. In: Bentley, B. \& T. Elias (Eds.). The Biology of Nectaries. Columbia University Press, New York.

Baker, H.G. \& I. Baker (1983b). Floral nectar sugar constituents in relation to pollinator type, pp.117-141. In: Jones, C.E. \& R.J. Little (Eds.). Handbook of Experimental Pollination Biology. Scientific and Academic Editions, New York.

Borkent, C. \& L. Greenway (1997). Natural History: Sphinx Moths (Family Sphingidae) in British Columbia. Biological Notes and Field Key based on specimens in the collection at the Royal British Columbia Museum, Electronic Document.

Dadd, R.H. (1973). Insect nutrition: current developments and metabolic implications. Annual Review of Entomology 18: 381-420.

Kumar, H.D. (2000). Plant Animal Interactions. East West Press. New Delhi, 400pp.

Meeuse, B. \& S. Morris (1984). The Sex Life of Flowers. Facts on File, New York, 148pp.

Rao, S.P., A.J.S. Raju \& P. Victor (2005). Steady state flowering pattern, temporal dioecism, facultative xenogamy and pollination by insects in Tecoma stans L. (Bignoniaceae). Journal of National Taiwan Museum 58: 109-116.

Raju, A.J.S., S.P. Rao, V. Ezradanam, R. Zafar, P.R. Kalpana \& P.K. Kumari (2004). The hawk moth, Macroglossum gyrans and its interaction with some plant species at Visakhapatnam. Zoos' Print Journal 19: 1595-1598. 